perial one is, however, highly laudable, and should be encouraged with a view to the unification of British medical science. It is further announced that a longdeferred step is about to be taken by the introduction of the metric system into the body of the work. In the present edition the centimetres and grammes of science appear modestly in the supplementary pages dealing with volumetric processes, and then only as an alternative to grains and "grain-measures." We understand that in the new revision centimetres and grammes will be made official in all the monographs of the text, side by side with the still legalised grains and ounces, minims and drachms. This change will bring the British handbook into line with the official dispensatories of all other civilised States, and should tend to hasten the time when the international system of metric weights and measures shall acquire full legal authority in this country.

It thus appears that the Medical Council's Committee have undertaken the task of revision with an adequate sense of their responsibility. They have in the suggestions of the medical authorities at home and abroad, and in the useful digests of the literature of pharmacy, prepared from year to year by their reporter, Prof. Attfield, ample materials whereon to base their deliberations. As a body of physicians representing the supreme council of the profession, they are eminently qualified to judge as to the requirements of practical medicine and clinical therapeutics. Where their domain borders on that of the specialist in chemistry, botany, pharmacy, or physiological pharmacology, they propose to have recourse to the most skilled representatives of these branches of science. The result of their labours, thus conceived and carried out, will be awaited with interest not only by practitioners of medicine and pharmacy, and by manufacturing chemists, but by all who have sympathy with the application of science to human needs.

\section{THE FIRST MERIDIAN.}

$\mathrm{A}^{\mathrm{T}}$ $\mathrm{T}$ the recent Geographical Congress in London, the question of the first meridian was discussed with particular interest.

It was proposed that the first meridian should not be established officially, but should merely be settled with a view to producing an international map to the scale of millionths. M. A. de Lapparent has written an article in La Nature on the subject, of which the following is an analysis; it is a noteworthy occurrence that a Frenchman should have taken up the subject with such interest, for the French has hitherto been the only nation to reject the Greenwich meridian. In the preliminary discussions they have brought upon themselves many reproaches for hindering a scientific work the use of which every one had recognised, while they themselves had no principle to bring forward to support their objections. The matter has been much discussed amongst them, and at the Geographical Society of Paris, by a special commission, it was decided that the map should be accepted. It was considered best that France should not be the only country to refuse the project ; nevertheless, it was decided to insist on the metric system being used, for here a principle was involved.

On this subject M. de Lapparent writes as follows :-

"Thus, true to its habit of fighting for its views, France has again showed itself champion of the metric system, offering to make, for the scientific and rational interest, a sacrifice of national self-love. It would be impossible for it to capitulate on the question of the system, for here a principle is concerned; but the choice of a meridian, depending on no logical consideration, could be more easily granted. Evidently the proposed map, if ever produced was to be arranged so as to be a help to already existing aps, the latter being in great majority on the No. I $35 \mathrm{I}$, VOL. 52 ] meridian of Greenwich ; by wishing to impose the meridian of Paris (which would not have been a success), it would have caused greater trouble than the contrary case. Henry IV. estimated that Paris was worth a mass; the French delegates, however, said on their side that the concession of a meridian, for a special and determined work, was quite worth the agreement which was expected to be established in view of the adoption, for the same purpose, of the metric system."

Many of our own countrymen have regretted that the public spirit prevented the system being used officially in Britain.

However, the acceptance of the Greenwich meridian well deserved a recompense, and the vote was unanimously carried that the metric system should be used for the map.

It is worth observing that the subject was discussed with remarkably few disagreements, considering that the congress was international. This seems to show that the time is fast approaching when national prejudices will be done away with if they support illogical theories; if principles are involved, it is right they should be adhered to, but they should not be allowed to hinder an enterprise profitable, perhaps, to all humanity.

\section{NOTES.}

THE Times of yesterday published a telegram, dated September I7, from Sandefiord, Norway, received through Reuter's Agency, stating that advices received at Sandefiord from the Danish trading station of Angmagsalik, on the east coast of Greenland, state that towards the end of July a three-masted ship, with a short foremast, was seen by Eskimos on two occasions firmly embedded in drift ice. On the first occasion the ship was observed off Sermiligak, $65^{\circ} 45^{\prime}$ lat. N., $36^{\circ}$ I $5^{\prime}$ long. W. ; and the second time off Sermelik. $65^{\circ} 20^{\prime}$ lat. N., $38^{\circ}$ long. W. It is believed tha the vessel was Dr. Nansen's Fram, and that she was on her return journey. In any case, however, no positive news of the exploring vessel is expected to arrive until next year.

ON Wednesday, Sept. II, a Reuter telegram announced that the steam yacht Windward, which took out the Jackson-Harmsworth Polar Expedition, had arrived at Vardö, and on Thursday another telegram, through the same Company's agency, stated that the expedition, after leaving Archangel, passed the winter on Franz Joseph Land, from which place a start was made in the middle of July. The crew appear to have suffered severely from scurvy, and all the members of it are more or less weakened by the malady. Three of the men succumbed, and two others were removed to the hospital at Vardö.

The Standard states that the excavations that are being carried out by the Greek Archrological Society on the site of ancient Eleusis, a few miles from Athens, have just yielded some results of exceptional importance. In a very ancient and wellpreserved tomb, there have been found, in addition to the skeleton of a woman, a number of articles, including earrings of fine gold, silver, and bronze, several finger rings, sixty-eight small vases of various shapes in terra-cotta, two tripods, three Egyptian scarabæi, and a small statuette of the goddess Isis in porcelain. These discoveries leave no doubt of the fact that the celebrated mysteries of Eleusis were of Egyptian origin, and were borrowed from the religious rites of the ancient Egyptians. These important relics have been deposited in the National Museum.

A Reuter's telegram of September i I, from Berne, reported the fall of a huge mass of ice from the Altels Glacier upon the hamlet of Spitalmatte, in the Upper Gemmi Pass, rausing the death of at least ten persons, and the loss of, it is estimated, two hundred head of cattle. A stretch of land nearly two miles 